\title{
Strengthening the Construction of College Students' Community in the Carrier of Ideological and Political Education
}

\author{
Peilun Shen1 DaMing Zhu1 YuJian Li1 LiHua Xue1 DianWen Liu1 \\ (1Faculty of Land Resource Engineering, Kunming University of Science and \\ Technology, Kunming 650093, China;)
}

\begin{abstract}
Under the new situation of diversified development of colleges and universities, we are trying to cultivate the talents featuring an all-round development of morality, intelligence and art. Strengthening college first education class as well as expanding the second class about college students' communities, which is the trend of the education development. As a result of college talents training mode reform in recent years, the university education management mode about class-oriented is increasing by weekend, and replaced by college Students' communities. For this reason, it is important to improve the construction of college students' communities in the new period. However, taking ideological education as the carries, constructing harmonious safety and advanced community is an important channel of university education.
\end{abstract}

Keywords-Students' community, second class, party construction

\section{INTRODUCTION}

Under the trend of colleges and universities diversity reform and development, the new words "university student community" emergent historic moment. As a new education platform, constructing and perfecting the environment of second class has became the important content of humanities construction. At present, the student-oriented about ideological and political education culture education community model is still on initial stage[1]. Therefore, it is the primary task to transform the function of Students' Community from management to educational cervices, and ideological education as The Carriers to construct the interconnected and related community broad educational category.

\section{PROBLEMS OF UNIVERSITY STUDENTS' COMMUNITY BUILDING}

\section{A. Weakness of Party and Youth League organizations}

The perfect community and Youth League organization is the important operation of university students community. Especially the party's advanced nature and the pioneering function of the party members. Because of lacking awareness about the importance of Party and Youth League organization in the Students' Community and ignoring the meaning of it.

Students community have grown away from the construction of Party and Youth League Organization and caused the loss of learning and communication platform. Specific in the staff of non-compliance, lacking of Basic-level organization, office work place, activities area and administrative organization.

\section{B. Non-systematic ideological Education}

As the reform of teaching system ,the cultivating model of credit hours system and elective system is forced, which gradually weakened the class-oriented management system, as well as the difference about regional culture and living habit, it is difficult for the ideological education weakens to implement management unified[2]. On the other hand ,because the lacking of counselor, in most cases ,the administrators deal with emergencies just as busy as firefighters.

Only take hard ware facilities and social management into consideration, but ignore the establishment of software and culture construction is the core problem of building ideological and political education system.

\section{IMPROVING THE PARTY AND YOUTH LEAGUE ORGANIZATION OF STUDENTS COMMUNITY}

As so far, university with multi-branch campus office is universal in China. It is still a difficulty for the college organize the party construction work with close connection and coordination, let alone develop the party construction into the community level. Party construction in grass-roots in the community is still in the blank stage. The traditional basic party branch construction has not adapted to the development of the new situation. So strengthening and improving the construction of grass-roots party branch of community with reformist spirit is necessary. In order to achieve the reasonable building of the student Community party branch target, it must rely on the core effects of the party organization.

First, set up party member service station. Strengthening the construction work of the station, which can provide the platform for party members to strengthen the party spirit, as well as enhance the sense of belongings and intimacy for the party members.

Secondly, set up student's party branch indifferent buildings. A good counselor and dorm can be as a secretary to ensure the right direction of development. We can also select excellent party members to be the assistants to develop various work in community[3]. Building party branch will cooperate and interpreter with the professional party branch to guarantee the management activities and safety of the community.

Thirdly, set up activities places in the community, such as cultural activities rooms, reading rooms, petition rooms, to ensure organization of grass-roots party more flexible, creative and cohesive. It can also prompt the party members to be the impellor and practitioners of the scientific development. 


\section{Strengthen Culture Construction Of The COMMUNITY}

The definition of cultural in Chinese is "humanities enlightenment", but the premise that only "human beings" "cultural" can be established, which means, internalized knowledge as spirit ,conviction, cultivation and personality. Strengthen culture construction of community is aiming for cultivation of people .It should also take the cultivation of socialist new talent ,adhering people-oriented principle ,focusing on the further development as the direction of community cultural construction .and take students growth as a supportive point ,combing the realities of the development of the community, with over all arrangement and systematic promoting create the harmonious cultural atmosphere. Under the development of diversified community ,strengthen cultural construction is not only the direct result of the model of the second class ,but also the extension and expansion of the first class education [4].

\section{A. Creating Brand Publication And Cultural Atmosphere}

For lacking of a good community cultural atmosphere, it is necessary to create a brand publication, which can open up the new situation

Newspapers and periodicals are replaced by network and electronic products, with the popularity of smart phone, computers and other electronic products, a lot of college students has become "self-centered", they have no sense to care the whole development of a team ,even indifferent to the traditional culture. The faster development of science and technology ,the more attention should we pay to the culture. Only the profound cultural heritage and history arouse our awareness ,can we train more excellent talents[5].

\section{B. Broaden The Propaganda Way, Outline spirit of humanities}

As a brand of social culture, the students' community culture is influenced by the social culture. Because of various culture and lacking of differentiate and analyzed ability, it is easy bring a negative influence to their political conviction and moralities [6-7].

At this point, the community culture builders should pay more attention to the persuasion of students' cultural information learning and the establishment and perfection of the publication platform , as well as guidance on the formation of the correct value and world view .

The way to build the propaganda platform is to give full play to the network two -sided and "avoid short" ,such as strengthen the construction of college website, Weibo and Wechat with three-dimensional publicity, Web-based to achieve the persuasion of students' cultural information learning target ,taking advantage of the buildings and other spaces in the community, just like propaganda posters[8].

\section{V.CONCLUSION:}

The construction of university community is a systematic, practical and long process. It needs the combined effects of the university and college students. It also needs the cooperation of community administrators and residential teachers.

Only connecting with the practical situation and innovating, can give full play to the second education class. It is an inevitable tendency to establish the idealism of humanity, fictionalization and liberalization community. We should set out actually, adhere the people-oriented intent and purpose of building community, colleges and universities should[9-10].

Take the construction of community with the strategic prospective view and wholly consideration, to create a diversified, safety, humanity and advanced community.

\section{REFERENCES}

[1] [1]Yantao Wu, WeiSong. University students thinking of community culture construction $[\mathrm{J}]$. Higher agricultural education.2013,(7):29-31.

[2] [2]Zhimei Wang, XingZhen Chen. The construction of multi-campus students' party construction coordination mechanism-- With Shanghai H college's practice of exploration for example $[\mathrm{J}]$. Ideological and theoretical education (The first half comprehensive version). 2012, (4):59-62.

[3] [3]Donghu Zhang. Thinking about the culture construction of college students community in the new era $[\mathrm{J}]$. In the western development (ten-day).2011,(1):10-15.

[4] [4]Liben Huang. Meaning and approach of party organization into student apartment $[\mathrm{J}]$. Journal of ZheJiang industry and commerce professional technology institute.2004, 3(1):38-39.

[5] [5]Wu Yueji. College students practice and thinking of community volunteer service $[\mathrm{J}]$. Journal of education and career, and practices of 2010:169-170.

[6] [6]Qian Weichao Liu Lanxing. Try to talk about college students community construction $[\mathrm{J}]$. Journal of suzhou university (philosophy and social sciences edition), 2010 and practices: 192-194.

[7] [7]Min Xiang, Jiang Deqi. Shallow theory after 90 college students' community culture construction [J]. Journal of reform and opening, 2009, 12:143-144.

[8] [8]Lina Tian. Long-term effective mechanism of community college students volunteer service $[\mathrm{J}]$. Journal of ideological education research, 2009, S2:103-106.

[9] [9]Wang Dingfu. The rational thinking of community college students study style construction $[\mathrm{J}]$. Journal of higher agricultural education, 2004, 12:81-83.

[10] [10]Exhibition. College students' community construction edge space analysis [J]. Journal of zhejiang wanli college, 2014, 12:94-97. 